\title{
Sidroma neuroleptik maligna patofisiologi, diagnosis, dan terapi
}

\author{
Mieke A. H. N. Kembuan \\ Bagian Neurologi Fakultas Kedokteran Universitas Sam Ratulangi \\ Email:dr.miekekembuan@yahoo.com
}

\begin{abstract}
Neuroleptic malignant syndrome (NMS) is an uncommon, neurological emergency, with a high mortality rate. This syndrome is related with neuroleptic drug consumption. It is potential to bring about fatal complication with physical findings such as fever, movement disorder, rigidity, altered mental status, and autonomic dysfunction. A retrospective study in India showed an incidence rate of $0.14 \%$, while in United States it reached $0.2-1.9 \%$. NMS is related to the disturbance of dopamine receptor due to unknown mechanism. Most people with NMS died from heart, lung, or kidney complications. Early diagnosis, halting the usage of offending drugs, best supportive medical treatment, and specific pharmacotherapy for 14-21 days can give a good clinical outcome
\end{abstract}

Keywords: NMS, neuroleptic drugs

\begin{abstract}
Abstrak: Sindroma neuroleptik maligna (SNM) jarang terjadi namun merupakan suatu kegawatdaruratan neurologi yang berpotensi mengancam nyawa. Sindroma ini berkaitan dengan penggunaan obat-obatan neuroleptik. SNM berpotensi menyebabkan komplikasi fatal yang diakibatkan oleh penggunaan obat-obat antipsikotik dengan gejala klinis berupa demam, gangguan gerak, rigiditas, perubahan kesadaran, dan disfungsi otonom. Suatu penelitian retrospektif di India menunjukkan angka insidens SNM 0,14\%, sedangkan di Amerika Serikat angka insidens tersebut mencapai $0,2-1,9 \%$. Patofisiologi sindroma ini berhubungan dengan jalur reseptor dopamin di otak dengan mekanisme yang belum jelas. Morbiditas dan mortalitas pada SNM sering merupakan akibat sekunder dari komplikasi jantung, paru-paru, dan ginjal. Keberhasilan tatalaksana SNM dapat dicapai melalui diagnosis dini yang tepat, penghentian obat-obat neuroleptik, perawatan medis suportif, dan farmakoterapi spesifik selama 14 sampai dengan 21 hari diikuti dengan perbaikan klinis.
\end{abstract}

Kata kunci: SNM, obat-obat neuroleptik

Sindroma neuroleptik maligna (SNM) merupakan suatu sindroma yang jarang terjadi namun termasuk sindroma kegawatdaruratan neurologi yang berpotensi mengancam nyawa dan berkaitan dengan penggunaan obat-obatan neuroleptik (antipsikotik). Munculnya sindroma ini dihubungkan dengan penggunaan segala obat neuroleptik, baik tipikal maupun atipikal. Umumnya sindroma ini memberkan gejala demam, kekakuan otot, perubahan status mental, dan gangguan otonom. Sindroma ini mempunyai onset dalam waktu beberapa jam setelah pemakaian obat neuroleptik, namun sebagian besar timbul dalam kurun waktu 4-14 hari setelah terapi dimulai. ${ }^{1-3}$

Pertama kali dijelaskan oleh Delay et al. pada tahun 1960-an bahwa sindroma ini berhubungan dengan penggunaan haloperidol. Data-data yang dikumpulkan dari tahun 1966-1997 menyatakan bahwa angka insidens SNM di Amerika berkisar antara $0.2-3.2 \%$ dari penderita psikotik yang mendapat terapi neuroleptik, namun karena semakin tingginya kejelian dokter dalam 
mengenali sindroma ini dan juga ketersediaan obat-obatan neuroleptik generasi baru maka insidensnya telah berkurang menjadi sekitar $0.01-0.02 \%{ }^{2}$

SNM dapat berakibat fatal dan angka mortalitas berkisar $5-20 \%$ bila tidak ditangani dengan baik. ${ }^{4}$

\section{LAPORAN KASUS}

Seorang perempuan berusia 58 tahun dirujuk ke UGD RSUP Prof. Dr. R. D. Kandou Manado dengan keluhan utama penurunan kesadaran yang dialami 4 hari sebelum masuk rumah sakit. Dari aloanamnesis diketahui sejak 4 hari sebelum masuk rumah sakit penderita tampak lemah dan cenderung tidur. Dua hari kemudian penderita mengalami kaku seluruh badan, tidak dapat membuka mulut, demam, dan gelisah. Riwayat penggunaan obat haloperidol yang diberikan secara intravena dan obat-obat seperti risperidon, triheksiphenidil, frimania, litium dan valdimex telah dikonsumsi secara oral sejak 2 minggu sebelum penderita mengalami penurunan kesadaran. Penderita adalah pasien kontrol dari RS Ratumbuysang dengan keluhan sering marah ataupun menangis tanpa alasan yang jelas disertai dengan bicara sendiri. Riwayat menderita tekanan darah tinggi, diabetes melitus, peningkatan kolesterol dan asam urat, penyakit jantung, penyakit ginjal, trauma kepala, infeksi, dan tumor otak disangkal.

Pada pemeriksaan fisik ditemukan keadaan umum sedang, kesadaran spoor dengan GCS $\mathrm{E}_{2} \mathrm{M}_{5} \mathrm{~V}_{3}$. Tekanan darah 130/70 mmHg, frekuensi nadi 108x /menit, reguler, isi cukup, frekuensi napas $24 \mathrm{x} /$ menit, reguler, suhu badan $38,5^{\circ} \mathrm{C}$, dan saturasi oksigen 98\%. Pemeriksaan status generalis dalam batas normal. Pemeriksaan neurologis ditemukan kuduk kaku dengan status motorik didapatkan tonus otot keempat anggota gerak meningkat, terdapat cogwheel rigidity, refleks fisiologis keempat anggota gerak dalam batas normal, tidak ditemukan refleks patologis keempat anggota gerak disertai gagguan otonom seperti hiperhidrosis dan hipersalivasi. Pemeriksaan laboratorium didapatkan peningkatan kreatinin kinase sebesar $8110 \mathrm{U} / \mathrm{L}$ sedangkan pemeriksaan penunjang lainnya tidak ditemukan kelainan.

Berdasarkan hasil anamnesis, pemeriksaan fisik dan pemeriksaan penunjang maka penderita didiagnosis sindroma neuroleptik maligna. Penatalaksanaan berupa penanganan kegawatdaruratan akibat penurunan kesadaran ditambahkan dengan antipiretik, bromokriptin dan triheksiphenidil.

\section{BAHASAN}

Sindroma neuroleptik maligna (SNM) jarang ditemukan namun merupakan suatu kegawatdaruratan neurologi yang berpotensi mengancam nyawa berkaitan dengan penggunaan obat-obatan neuroleptik dengan karakteristik demam, rigiditas, disfungsi otonom dan perubahan status mental. Munculnya sindroma ini dihubungkan dengan penggunaan berbagai obat neuroleptik, baik tipikal (generasi pertama) maupun atipikal (generasi kedua). Walaupun jarang, namun sindroma ini dilaporkan dapat juga timbul akibat penggunaan obat-obatan non neuroleptik yang mempunyai aktivitas antidopaminergik seperti misalnya metoklopramid, promethazine, tetrabenazine, droperidol, diatrizoate amoxapine, clomipramine, desipramine, litium, amantadine, carbamazepine, dan L-dopa (Tabel 1). ${ }^{1,2,5}$.

Pada kasus ini penderita mendapatkan terapi obat per oral haloperidol, frimania, triheksifenidil, dan valdimex yaitu obatobatan neuroleptik yang dapat menyebabkan SNM. Disamping itu terdapat beberapa faktor risiko yang dapat menimbulkan SMN seperti dosis obat neuroleptik yang tinggi, peningkatan dosis obat secara cepat dalam waktu singkat, pemberian secara parenteral, kombinasi obat neuroleptik, dehidrasi, demam dan lain-lain. ${ }^{6,7}$ Pada kasus ini didapatkan faktor risiko berupa dosis obat neuroleptik yang tinggi, pemberian obat neuroleptik secara 
parenteral, kombinasi 2 atau lebih obat neuroleptik, dan penggunaan obat neuroleptik bersama obat lain seperti litium. Tabel 2 memaparkan lebih lanjut faktor-faktor risiko yang dapat memicu timbulnya sindroma ini.

Onset terjadinya SNM cukup cepat. Beberapa penderita dapat terjadi SNM setelah mendapatkan neuroleptik dosis besar tunggal, sebagian penderita terjadi SNM setelah 1-3 hari dimulai penggunaan neuroleptik, dan sebagian besar penderita memperlihatkan gejala dalam waktu 4-14 hari setelah dimulainya penggunaan neuroleptik. ${ }^{1,2,8-12}$.

Tabel 1. Pembagian obat-obatan yang dapat menyebabkan sindroma neuroleptik maligna ${ }^{2,5,12-14}$

\begin{tabular}{clc}
\hline \multicolumn{1}{c}{ Tipikal } & Neuroleptik & Non-neuroleptik dengan \\
Atipikal & aktivitas antidopaminergik \\
\hline Potensi rendah: & Aripiprazole & Metoklopramide \\
Klorpromazin & Asenapine & Tetrabenazine \\
Proklorperazin & Clozapine & Reserpine \\
Thioridazin & Iloperidone & Droperidol \\
& Lurasidone & Prometazine \\
& Olanzapine & Amoxapine \\
Qutensi tinggi: & Quetiapin & Diatrizoate \\
Haloperidol & Paliperidon & Dopaminergik (withdrawal) \\
Flufenazin & Risperidon & Levodopa \\
Pimozide & Ziprasidone & Dopamin agonis \\
Thiotixene & & Amantadine \\
& & Tolcapone \\
& & Lainnya \\
& & Litium \\
& & Phenelzine \\
& & Dosulepin \\
& & Desipramine \\
& & Trimipramine \\
\hline
\end{tabular}

Tabel 2. Faktor-faktor risiko yang dapat memicu timbulnya $\mathrm{SNM}^{1,2,5-8,12,13}$

\begin{tabular}{cll}
\hline Hubungan dengan obat & Hubungan dengan somatik & $\begin{array}{c}\text { Hubungan dengan kondisi } \\
\text { kejiwaan }\end{array}$ \\
\hline $\begin{array}{c}\text { Dosis obat neuroleptik yang } \\
\text { tinggi }\end{array}$ & Dehidrasi & $\begin{array}{c}\text { Agitasi psikomotor } \\
\text { Riwayat gangguan } \\
\text { afektif }\end{array}$ \\
Peningkatan dosis obat & Demam & \\
neuroleptik secara cepat & Genetik & \\
dalam waktu singkat & Trauma & \\
Penggantian mendadak obat & Infeksi & \\
neuroleptik & Malnutrisi & \\
Pemberian obat neuroleptik & Alkoholisme & \\
secara parenteral & Tirotoksikosis & \\
Kombinasi 2 atau lebih obat & Kelainan otak organic \\
neuroleptik & Hiponatremia & \\
Penggunaan obat neuroleptik & Usia muda & \\
bersama obat lain seperti & Laki-laki & \\
litium & Defisiensi besi & \\
Riwayat SNM sebelumnya & & \\
\hline
\end{tabular}


Efek samping obat neuroleptik sangat penting untuk diketahui mengingat penggunaan obat ini seringkali diberikan dalam jangka panjang. Efek-efek samping tersebut mencakup efek ekstrapiramidal (distonia, parkinsonisme, akathisia dan tardive dyskinesia), efek antikolinergik (mata kabur, mulut kering, bingung, konstipasi, retensi urin), hipotensi ortostatik, kepala terasa melayang, disfungsi seksual, amenorea, sedasi, kejang, gangguan hematologik (agranulositosis), dan SNM. $^{6}$ Pada kasus ini penderita mendapatkan obat neuroleptik yang berefek samping terjadinya SNM.

Obat neuroleptik bekerja pada reseptor dopamin. Pada jaringan otak, dopamin mempunyai 4 jalur utama, yaitu jalur nigrostriatal, mesolimbik, mesokortikal dan tuberoinfundibular. Jalur nigrostriatal mengirimkan dopamin dari substansia nigra menuju striatum atau ganglia basalis. Jalur ini merupakan bagian dari sistem ekstrapiramidal dan berperan pada regulasi motorik. Defisiensi dopamin pada jalur ini dapat menimbulkan gangguan gerak seperti parkinsonism yang ditandai dengan tremor, rigiditas dan akinesia. Jalur mesolimbik mengirimkan dopamin dari area ventral tegmental (AVT) ke nukleus akumbens dan berperan pada motivasi, emosi, interaksi social, dan gejala positif pada skizofrenia. Defisiensi dopamin pada jalur ini mengakibatkan kehilangan motivasi, perasaan tidak puas, dan anhedonia. Jalur mesokortikal mengirim-kan dopamin dari AVT ke korteks prefrontal, dan terbagi menjadi dua, yaitu: jalur yang mengirimkan dopamin dari AVT ke dorsolateral korteks prefrontal (DLPFC) dan jalur lainnya mengirimkan dopamin dari AVT ke ventromedial korteks prefrontal (VMPFC). Jalur mesokortikal berperan pada kognisi, fungsi eksekusi, emosi dan afek. Defisiensi dopamin pada jalur ini mengakibatkan penurunan kognisi, afek dan menimbulkan gejala negatif. Jalur tuberoinfundibular mengirimkan dopamin dari hipotalamus ke hipofise anterior dan memengaruhi hormon prolaktin. Gangguan pada jalur ini dapat mengakibatkan peningkatan sekresi prolaktin yang akan menyebabkan galaktorea, amenorea, dan disfungsi seksual. $^{13}$

Patofisiologi SNM sebenarnya belum sepenuhnya dimengerti. Pada Gambar 1 dan 2 dijelaskan patofisiologi terjadinya SNM akibat penggunaan obat neuroleptik. Sebagian besar pakar setuju bahwa penurunan bermakna dari aktivitas dopaminergik sentral yang diakibatkan oleh blokade reseptor dopamin D2 pada jalur nigrostriatal, tuberoinfundibular, dan mesolimbik/kortikal membantu menerangkan gambaran klinis SNM termasuk rigiditas, hipertermia, dan perubahan status mental. Teori ini didukung dengan pengamatan bahwa penyebab utama SNM ialah penggunaan obat-obatan neuroleptik yang menghambat reseptor dopamin khususnya reseptor D2, dan bahwa sindroma ini dapat diinduksi oleh penghentian dopamin secara mendadak $1,2,5,6,11-13$

Antagonis reseptor dopamin D2 tidak sepenuhnya menjelaskan keseluruhan tanda dan gejala klinis SNM, dan juga tidak menjelaskan timbulnya SNM dengan obat neuroleptik potensi rendah dan juga obatobatan yang tidak mempunyai aktivitas antidopaminergik. Hal ini membuat beberapa ahli mengajukan hipotesis bahwa hiperaktivitas simpatoadrenal, yang diakibatkan oleh peniadaan inhibisi tonik dalam sistem saraf simpatis, dapat berperan dalam patogenesis SNM. Abnormalitas sistem simpatis didukung dengan seringnya timbul gejala otonom pada SNM seperti ketidakstabilan tekanan darah, laju nadi, diaforesis, serta terdapatnya perubahan kadar katekolamin plasma dan urin., 2,6,12,13 Sistem lain yang juga diduga ikut berperan pada timbulnya tanda dan gejala SNM ialah sistem otot skeletal perifer. Penggunaan neuroleptik berkaitan dengan peningkatan pelepasan kalsium dari retikulum sarkoplasma serat otot, sehingga mungkin menyebabkan peningkatan kontraktilitas dan rigiditas otot, kerusakan otot, serta hipertermia., ${ }^{1,6,12}$ 


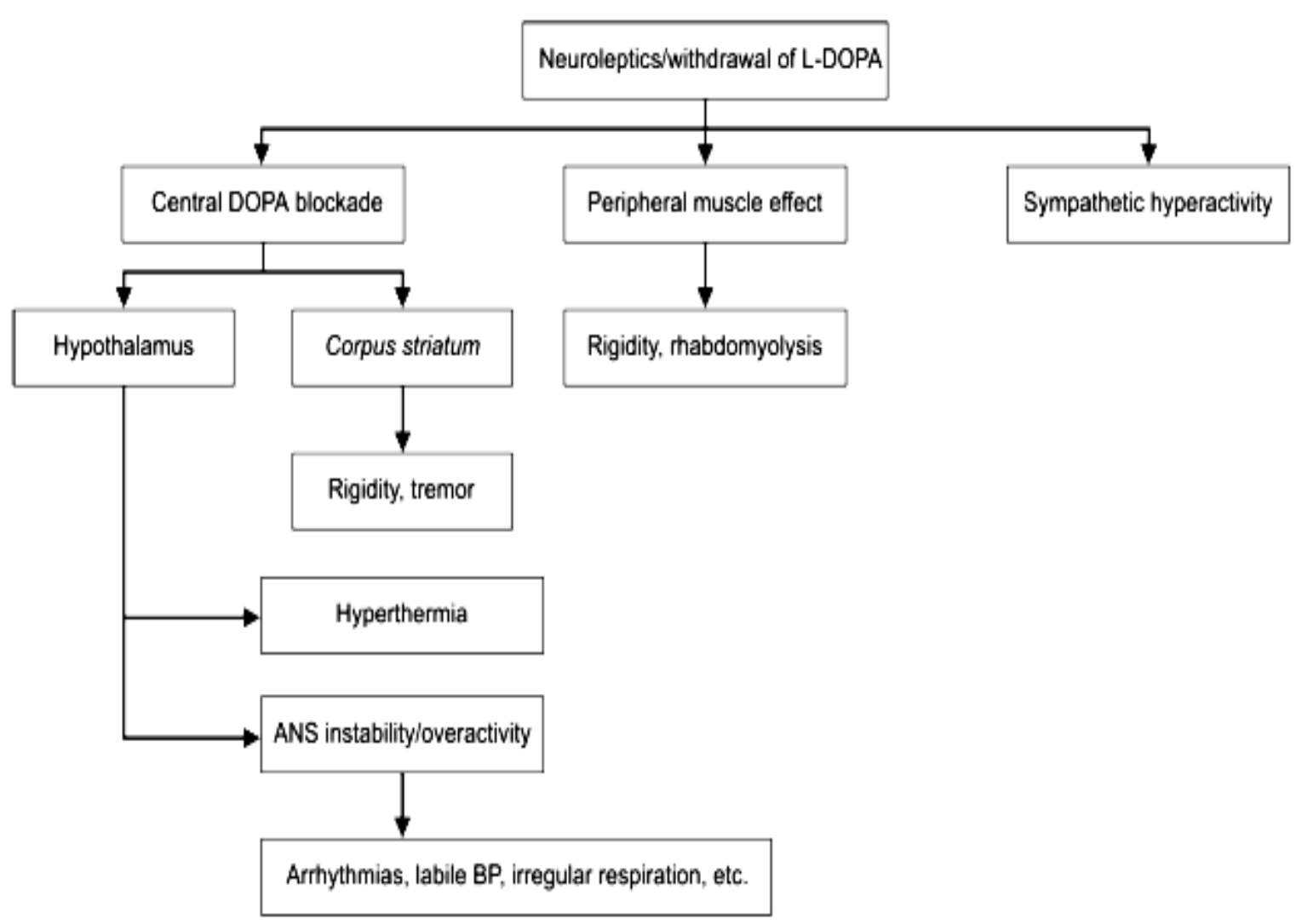

Gambar 1. Bagan patofisiologi sindroma neuroleptik maligna ${ }^{1}$

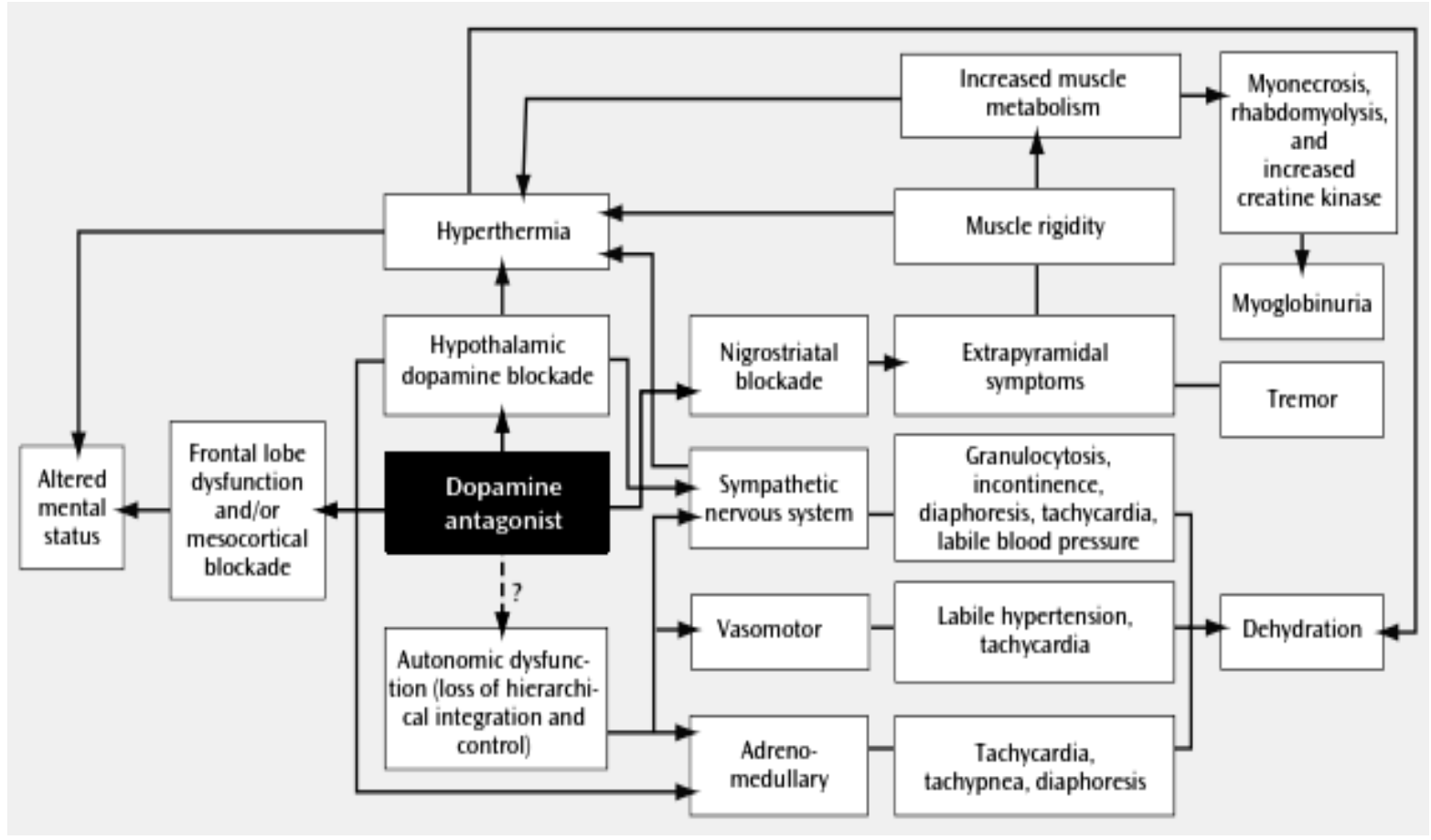

Gambar 2. Bagan patofisiologi sindroma neuroleptik maligna ${ }^{13}$ 
Pusat kontrol sistem termoregulasi tubuh terletak di hipotalamus anterior yang bertanggung jawab akan pemeliharaan homeostasis termal tubuh. Sinyal sensorik dari termoreseptor dikirim ke hipotalamus anterior yang akan dibandingkan dengan "set point". Mekanisme efektor dari termoregulasi (secara fisik dan perilaku) selanjutnya diaktifkan dan suhu tubuh dikompensasi sejalan dengan "set point" dengan cara produksi dan pelepasan panas. Mekanisme terjadinya hiperpireksia pada SNM disebabkan karena adanya elevasi pada "set point", yang dipicu oleh zat yang dikenal sebagai pirogen, baik pirogen eksogen maupun endogen. Saat ini disepakati bahwa faktor-faktor yang mengaktivasi sintesis pirogen endogen tubuh disebabkan oleh pirogen eksogen. Hasil beberapa penelitian yang menelaah mekanisme demam menunjukkan bahwa zat pirogen eksogen dapat berupa bakteri, virus, protozoa, jamur, alkaloid atau lektin. Berdasarkan hal ini, obat neuroleptik dipikirkan sebagai salah satu pirogen eksogen yang mengaktivasi sintesis dan pelepasan pirogen endogen yang selanjutnya akan meningkatkan "set point" sehingga terjadi hiperpireksia pada SNM. Pirogen eksogen mengaktivasi sel sistem imun untuk memroduksi pirogen endogen seperti interleukin $1,6,8,11,12$, dan 18 , interferon $\gamma-\beta-\alpha$, tumor necrosis factor $\alpha-\beta$, dan sitokin lain seperti MIP-1 dan AFGF. Protein-protein tersebut diproduksi oleh monosit, granulosit, makrofag, dan limfosit T. Selain menyebabkan hiperpireksia, pirogen juga dapat menyebabkan ketidakstabilan fungsi otonom (perubahan tekanan darah dan takikardia), anoreksia, somnolen, merangsang produksi protein fase akut, pengaktifan aksis neurohormonal, serta efek sedasi. $^{5}$

Hingga saat ini tidak ada satupun teori yang dapat menjelaskan mengapa hanya pada sebagian kecil penderita yang mengonsumsi obat neuroleptik terjadi SNM. Selin itu juga belum dipahami mengapa penderita SNM biasanya dapat melanjutkan pengobatan neuroleptik dengan obat yang serupa dan bahkan dengan obat yang sama. ${ }^{2}$

Penegakan diagnosis pada kasus SNM memerlukan anamnesis yang cermat terutama mengenai riwayat pemakaian obat neuroleptik, jalur pemberian, dan lama pemberian. Di samping anamnesis, pemeriksaan fisik dan pemeriksaan penunjang juga dibutuhkan untuk menegakkan diagnosis. SNM merupakan sindroma yang jarang terjadi namun berpotensi membahayakan nyawa sehingga penegakan diagnosis yang cepat diikuti tatalaksana yang tepat sangat menentukan prognosis penderita. Empat gejala klasik SNM meliputi gejala motorik (rigiditas otot, bradikinesia, distonia, mutisme, korea, tremor), hipertermia, perubahan status mental (bingung, delirium, stupor, koma), dan instabilitas otonom (iregularitas pernapasan, aritmia jantung, tekanan darah yang tidak stabil, diaforesis). Pemeriksaan laboratorium yang khas ialah adanya peningkatan enzim kreatinin kinase $(\mathrm{CK})$ di atas $1000 \mathrm{IU} / \mathrm{L}$ (lebih dari 90\% kasus), dan dapat mencapai hingga 100000 IU/L, lekositosis berkisar $10000-40000 / \mathrm{mm}^{3}$, peningkatan ringan enzim laktat dehidrogenase (LDH), abnormalitas fungsi hati (peningkatan SGOT/SGPT). Mioglobinuria dapat diakibatkan proses rabdomiolisis yang dapat menyebabkan gagal ginjal akut.

Terdapat beberapa kriteria diagnosis yang dapat digunakan untuk menegakkan diagnosis SNM seperti Levenson's Diagnostic Criteria (1985), Addonizio Diagnostic Criteria (1986), Pope Diagnostic Criteria (1986), Adityanthee Diagnostic Criteria (1988), Lazarus et al (1989), Caroff et al (1991), Caroff and Mann Diagnostic Criteria (1993) dan DSM-IV-TR (Diagnostic and Statistical Manual of Mental Disorder-Fourth Edition-Text Revision) tahun 2000. ${ }^{1,9,13}$ Kriteria diagnosis berdasarkan Levenson (1985) yaitu: $:^{1,10}$

A. Gejala mayor: demam, rigiditas, dan peningkatan enzim $\mathrm{CK}$

B. Gejala minor: abnormalitas tekanan darah, takikardia, takipnu, perubahan kesadaran, diaforesis, dan leukositosis 
Pada kasus ini penegakan diagnosis SNM menggunakan kriteria Levenson, yaitu dibutuhkan 3 gejala mayor atau 2 gejala mayor dengan 4 gejala minor. ${ }^{1,10}$ Sesuai dengan kriteria Levenson, kasus ini memperlihatkan gejala demam, rigiditas, peningkatan enzim CK, takikardia, perubahan kesadaran, diaphoresis, dan lekositosis.

Disamping itu terdapat kriteria lain yang dapat digunakan untuk mendiagnosis SNM yaitu kriteria diagnosis berdasarkan DSM-IV-TR (2000), yaitu: ${ }^{1,6,11,13}$

A. Terjadinya rigiditas otot dan peningkatan suhu tubuh yang berkaitan dengan penggunaan obat neuroleptik

B. Dua atau lebih gejala berikut: Diaforesis, tekanan darah yang meningkat atau tidak stabil, takikardia, inkontinensia, disfagia, mutisme, tremor, perubahan status mental, dari bingung hingga koma, leukositosis, dan bukti laboratorik berupa lesi otot (peningkatan enzim CK)

C. Gejala pada kriteria A dan B bukan disebabkan karena zat lain, kondisi medik, atau neurologik lain

D. Gejala pada kriteria A dan B bukan disebabkan karena gangguan mental

Penegakan diagnosis SNM menggunakan kriteria DSM-IV membutuhkan 2 dari kriteria A dan setidaknya 2 dari kriteria B. ${ }^{1,10,13}$ Kasus ini memperlihatkan gejala demam, rigiditas, peningkatan enzim $\mathrm{CK}$, takikardia, perubahan status mental, diaforesis dan lekositosis. Kedua kasus tersebut sesuai dengan kriteria diagnosis SNM menurut DSM-IV-TR.

Evaluasi tingkat keparahan SNM menggunakan stadium Woodbury stage. Berdasarkan tingkat keparahan maka dapat diketahui manifestasi klinik dan penatalaksanaan yang harus dilakukan. Berdasarkan manifestasi klinis yang ditemukan, kasus ini tergolong pada stadium IV. Tabel 3 menjelaskan Woodbury stage yang disertai dengan manifestasi klinik dan tatalaksananya. ${ }^{13}$ $\begin{array}{rrrr}\text { SNM } & \text { merupakan } & \text { suatu kegawat- } \\ \text { daruratan } & \text { neurologi } & \text { dan } & \text { dapat }\end{array}$ menimbulkan kematian jika tidak segera diobati. ${ }^{1,2}$ Berhubung kasus ini sangat jarang, uji klinis sistematis kasus SNM sulit dilaksanakan sehingga sampai saat ini tidak ada tatalaksana berbasis bukti (evidencebased treatment). ${ }^{2,8,13}$ Tatalaksana SNM berdasarkan presentasi klinis, namun langkah awal ialah penghentian obatobatan neuroleptik yang diduga memicu timbulnya sindroma ini. Langkah selanjutnya ialah diberikan terapi suportif. Hidrasi agresif sering dibutuhkan, khususnya bila kadar CK yang terlalu tinggi dapat mengakibatkan kerusakan ginjal, dan penanganan hipertermia meliputi selimut dingin atau es batu di daerah aksila dan inguinal. Koreksi faktor metabolik bila ditemukan kelainan. Benzodiazepin dapat diberikan untuk mengurangi gejala SNM dan meningkatkan prognosis. $2,8,11-13$

Pada kasus SNM yang berat dapat diberikan terapi empirik seperti bromokriptin dan dantrolen. Bromokriptin merupakan suatu agonis dopamin, sedangkan dantrolene ialah relaksan otot yang bekerja dengan menghambat pelepasan kalsium dari retikulum sarkoplasma. Bromokriptin berguna untuk membalikkan keadaan hipodopaminergik dan diberikan secara oral atau via nasogastric tube (NGT), dimulai dengan dosis 2,5 mg 2-3 kali per hari dan dosis ditingkatkan 2,5 mg setiap 24 jam hingga timbul respon atau hingga dosis maksimal tercapai yaitu $45 \mathrm{mg}$ per hari. , $^{2,11-13}$

Dantrolene dapat diberikan secara intravena, dimulai dengan dosis awal 1 sampai 2,5 mg per $\mathrm{kgBB}$ secara bolus, diikuti dengan dosis $1 \mathrm{mg}$ per $\mathrm{kgBB}$ setiap 6 jam hingga dosis maksimal $10 \mathrm{mg}$ per $\mathrm{kgBB}$ per hari. Dantrolene oral diberikan untuk kasus yang lebih ringan atau untuk tappering down dari dosis intravena setelah beberapa hari dengan dosis berkisar 50-200 mg per hari. Karena risiko hepatotoksisitas, dantrolene biasanya dihentikan setelah 
gejala membaik. Bromokriptin umumnya dipertahankan untuk setidaknya 10 hari pada kasus SNM dengan neuroleptik oral dan setidaknya 2-3 minggu untuk neuroleptik injeksi. Obat lain yang dapat diberikan ialah golongan benzodiazepin, yang dapat membantu meringankan agitasi. ${ }^{4}$ Terapi tidak boleh dihentikan mendadak walaupun gejala klinis membaik karena dapat menyebabkan kambuhnya SNM. Terapi elektrokonvulsif diberikan kepada para penderita yang tidak menunjukkan respon terhadap pengobatan dan terapi suportif. ${ }^{1,2,8,11-13}$

Pada kasus ini dilakukan terapi suportif dengan penghentian segera obat-obatan neuroleptik, oksigenasi yang adekuat, tablet parasetamol $500 \mathrm{mg}$ per 8 jam, pemberian cairan intravena $\mathrm{NaCl} 0,9 \% 500 \mathrm{cc}$ per 12 jam. Terapi farmakologi spesifik dengan pemberian bromokriptin dosis $2,5 \mathrm{mg}$ per 12 jam kemudian dinaikkan secara bertahap sampai total dosis $7,5 \mathrm{mg}$ per hari yang dibagi dalam 3 dosis. Keluarga diedukasi agar bromokriptin dilanjutkan sampai 1421 hari setelah gejala SNM hilang kemudian diturunkan secara bertahap. Pemilihan preparat bromokriptin mengacu pada kondisi medis penderita berdasarkan stadiumnya serta ketersediaan bromokriptin yang lebih mudah didapatkan dibanding obat lain yang direkomendasikan.

Angka mortalitas kasus SNM >30\%, namun bila ditangani secepat mungkin maka angka mortalitas akan menurun sampai $10 \%$. Bila dikenali secara dini dan segera ditatalaksana, biasanya SNM tidak berakibat fatal dan sebagian besar penderita akan sembuh sempurna dalam jangka waktu 2-14 hari. Namun bila diagnosis dan tatalaksana terlambat, penyembuhan dapat berlangsung beberapa minggu atau lebih lama, dan penderita yang mampu bertahan hidup dapat mengalami katatonia residual atau parkinsonism, atau morbiditas yang berhubungan dengan komplikasi renal atau kardiopulmonar. $^{2}$

Tabel 3. Stadium SNM, manifestasi klinis dan tatalaksananya ${ }^{13}$

\begin{tabular}{|c|c|c|c|c|}
\hline $\begin{array}{c}\text { Stadium } \\
\text { Woodbury }\end{array}$ & $\begin{array}{l}\text { Manifestasi } \\
\text { klinis }\end{array}$ & Terapi suportif & $\begin{array}{c}\text { Intervensi lini } \\
\text { pertama }\end{array}$ & $\begin{array}{c}\text { Intervensi lini } \\
\text { kedua }\end{array}$ \\
\hline $\begin{array}{l}\text { I: parkinsonism } \\
\text { diinduksi obat }\end{array}$ & Rigiditas, tremor & $\downarrow$ atau ganti neuroleptik & Obat antikolinergik & \\
\hline $\begin{array}{l}\text { II: katatonia } \\
\text { diinduksi obat }\end{array}$ & $\begin{array}{l}\text { Rigiditas, mutism, } \\
\text { stupor }\end{array}$ & $\begin{array}{l}\text { Hentikan, } \downarrow \text { atau ganti } \\
\text { neuroleptik }\end{array}$ & $\begin{array}{l}\text { Lorazepam (1-2 mg im } \\
\text { atau iv setiap 4-6 jam) }\end{array}$ & \\
\hline III: SNM ringan & $\begin{array}{l}\text { Rigiditas ringan; } \\
\text { katatonia atau } \\
\text { kebingungan; } \\
\text { suhu } \leq 38^{\circ} \mathrm{C} \text {, nadi } \\
\leq 100 \mathrm{x} / \text { menit }\end{array}$ & $\begin{array}{l}\text { Hentikan neuroleptik, } \\
\text { awasi perkembangan } \\
\text { penyakit, koreksi faktor } \\
\text { risiko }\end{array}$ & $\begin{array}{l}\text { Lorazepam (1-2 mg im } \\
\text { atau iv setiap 4-6 jam) }\end{array}$ & \\
\hline $\begin{array}{r}\text { IV: } \text { SNM } \\
\text { sedang }\end{array}$ & $\begin{array}{l}\text { Rigiditas sedang; } \\
\text { katatonia atau } \\
\text { kebingungan; } \\
\text { suhu } 38-40^{\circ} \mathrm{C} \text {, } \\
\text { nadi } 100-120 \\
\text { x/menit }\end{array}$ & $\begin{array}{l}\text { Hentikan neuroleptik, } \\
\text { atur cairan, mulai } \\
\text { langkah pendinginan, } \\
\text { koreksi faktor risiko, } \\
\text { berikan perawatan } \\
\text { intensif }\end{array}$ & $\begin{array}{l}\text { Lorazepam (1-2 mg im } \\
\text { atau iv setiap 4-6 jam), } \\
\text { bromokriptin }(2,5-5 \mathrm{mg} \\
\text { po / NGT tiap } 8 \text { jam), } \\
\text { atau amantadine (100 } \\
\text { mg pe oral atau NGT } \\
\text { tiap } 8 \text { jam) }\end{array}$ & $\begin{array}{l}\text { Pertimbangkan } \\
\text { ECT (6-10 } \\
\text { perawatan } \\
\text { bilateral) }\end{array}$ \\
\hline V: SNM berat & $\begin{array}{l}\text { Rigiditas berat; } \\
\text { katatonia atau } \\
\text { koma; suhu } \\
\geq 40^{\circ} \mathrm{C} \text {, nadi } \geq 120 \\
\mathrm{x} / \text { menit }\end{array}$ & $\begin{array}{l}\text { Hentikan neuroleptik, } \\
\text { atur cairan, mulai } \\
\text { langkah pendinginan, } \\
\text { koreksi faktor risiko, } \\
\text { berikan perawatan } \\
\text { intensif }\end{array}$ & $\begin{array}{l}\text { Dantrolene (1-2,5 mg } \\
\text { per kgBB iv tiap } 6 \text { jam } \\
\text { untuk } 48 \text { jam, di taper), } \\
\text { bromokriptin }(2,5-5 \mathrm{mg} \\
\text { po / NGT tiap } 8 \text { jam), } \\
\text { atau amantadine ( } 100 \\
\text { mg per oral / NGT tiap } \\
8 \text { jam) }\end{array}$ & $\begin{array}{l}\text { Pertimbangkan } \\
\text { ECT (6-10 } \\
\text { perawatan } \\
\text { bilateral) }\end{array}$ \\
\hline
\end{tabular}




\section{SIMPULAN}

Sindroma neuroleptik maligna (SNM) adalah suatu sindroma kegawatdaruratan neurologi yang berpotensi mengancam nyawa yang berkaitan dengan penggunaan obat-obatan neuroleptik. Sindroma ini dapat berakibat fatal dan angka mortalitas berkisar 5-20\% bila tidak ditangani dengan baik. Kematian biasanya disebabkan oleh komplikasi aritmia, DIC, gagal jantung, gagal napas, dan gagal ginjal.

Deteksi awal dari gejala klinis SNM dan penanganan sesegera mungkin dapat meningkatkan luaran. Sindroma ini biasanya tidak fatal dan sebagian besar penderita akan pulih total dalam jangka waktu 2-14 hari. Walaupun belum ada panduan baku, tatalaksana sindroma ini berkaitan dengan penghentian obat-obatan neuroleptik yang diduga memicu timbulnya sindroma ini, terapi suportif, koreksi factor metabolik bila ditemukan kelainan.

\section{DAFTAR PUSTAKA}

1. Bhandari G. Neuroleptic malignant syndrome. Chapter 118. Available from: www.apiindia.org/medicine update_2013/chap118.pdf.

2. Berman BD. Neuroleptic malignant syndrome: A review for neurohospitalists. Neurohospitalist. 2011;1(1):41-7.

3. Nisijima K, Shioda $\mathbf{K}$. Temporal changes in serum creatine kinase concentration and degree of muscle rigidity in 24 patients with neuroleptic malignant syndrome. Neuropsychiatr Dis Treat. 2013;9: 853-9.

4. Tsai MC, Huang TL. Severe neuroleptic malignant syndrome: Successful treatment with high-dose lorazepam and diazepam: A case report. Chang Guang Med J. 2010;33(5):9.

5. Szota A, Oglodek E, Araszkiewicz A. Fever development in neuroleptic malignant syndrome during treatment with olanzapine and Clozapine. Pharmacol Rep. 2013;65: 279-87.

6. Langan J, Martin D, Shajahan P, Smith DJ. Antipsychotic dose escalation as a trigger for neuroleptic malignant syndrome (NMS): literature review and case series report. BMC Psychiatry. 2012;12:1-8.

7. Anglin RE, Rosebush PI, Mazurek MF. Neuroleptic malignant syndrome: a neuroimmunologic hypothesis. CMAJ. 2010;182(18):834-8.

8. Ouyang Z, Chu L. A case of recurrent neuroleptic malignant syndrome. Shanghai Arch Psychiatry. 2013;25(4):256-8.

9. Nisijima K, Shioda K. A rare case of neuroleptic malignant syndrome without elevated serum creatine kinase. Neuropsychiatr Dis Treat. 2014;10:403-7.

10. Nisijima K. Elevated creatine kinase does not necessarily correspond temporally with onset of muscle rigidity in neuroleptic malignant syndrome: a report of two cases. Neuropsychiatr Dis Treat. 2012;8:615-8.

11. Paul M, Michael SG, John S, Lenox RJ. An atypical presentation of neuroleptic malignant syndrome: Diagnostic dilemma in a critical care setting. Respir Care. 2012;57(2):315-7.

12. Cheah MF, Liew KB. A case report on haloperidol-induced neuroleptic malignant syndrome (NMS). JPCS. 2013;7:22-5.

13. Strawn JR, Keck PE, Caroff SN. Neuroleptic Malignant Syndrome. Am J Psychiatry. 2007;164:870-5. 